Ключевые слова: криминалистическая характеристика, обстановка преступления, место преступления, время преступления, доведение до самоубийства, кибербуллинг.

\title{
THE ROLE OF THE SITUATION IN THE STRUCTURE OF DRIVING TO SUICIDE MECHANISM
}

\begin{abstract}
Kerik L. I.
The article deals with the role of the situation in the structure of driving to suicide mechanism. The situation of driving to suicide is differentiated into stages of its development, the article also determines temporal connections of this crime and distinguishes types of driving to suicide places with the focus on the role of these elements in criminalistic characteristics of crimes as well as and their interconnections. A place of driving to suicide is a place, where preparations prior to the crime have been carried out, the crime had been committed (threats, cruel treatment, systematic humiliation of human dignity, blackmail); a place with traces and evidence of a criminal trespass (place of suicide); place of concealment of traces and evidence of the crime, instruments and facilities of its commission, the object of a criminal trespass (staging of suicide, murder). The time of driving to suicide allows establishing the sequence and development of different processes. The situation of driving to suicide consists of non-interference and omission by individuals (relatives, colleagues, friends and others) in whose presence a criminal mistreats or humiliates the personal dignity of the victim.

Keywords: criminalistic characteristic, crime conditions, crime scene, crime time, driving to suicide, cyberbullying.
\end{abstract}

O. I. Резнікова, науковий співробітник НДІ вивчення проблем злочинності імені академіка В. В. Сташиса НАПрН України

\section{ПРОБЛЕМИ ВИКОРИСТАННЯ ВІКТИМОЛОГІЧНИХ ДАНИХ У ПРОЦЕСІ ПІДГОТОВКИ ТА ПРОВЕДЕННЯ СЛІДЧИХ (РОЗШУКОВИХ) ДІЙ}

Розглянуто криміналістичний аспект проблеми використання віктимологічних даних під час підготовки та проведення слідчих (розшукових) дій, установлено основні проблеми використання таких даних $і$ шляхи їх подолання. Запропоновано окремі науково-практичні рекомендації, покликані підвищити ефективність прочесу збирання й використання віктимологічних даних у кримінальному провадженні.

Ключові слова: жертва злочину, потерпілий, віктимологічні дані, програма дослідження жертви (потерпілого), профіль жертви (потерпілого), слідчі (розшукові) діi.

(C) Резнікова О. І., 2015 
Складні соціально-економічні умови життя в Україні, дестабілізація політичної ситуації, терористична діяльність численних злочинних організацій у поєднанні із зовнішньою військовою агресією проти нашої держави призвели до збільшення рівня злочинності, приниження ролі закріплених у Конституції України «найвищих соціальних цінностей» людини: ії життя та здоров'я, честі й гідності, недоторканності та безпеки. Такі обставини провокують збільшення кількості жертв злочинів і потерпілих у кримінальних провадженнях, а також загиблих осіб у результаті вчинення таких злочинів ${ }^{1}$.

Сучасні загрози, що існують на території України вимагають адекватної реакції держави та суспільства. Проведення антитерористичної операції в Україні, боротьба з корупцією в правоохоронних органах призводить до постійного їх реформування й оновлення кадрового складу, що не завжди позитивно впливає на процес боротьби зі злочинністю. Проблеми в правозастосовній практиці України вимагають сучасного і якісного наукового забезпечення правоохоронної діяльності органів державної влади на кожному окремому етапі їх роботи, яке покликана й здатна надати вітчизняна криміналістика. Важливою сферою криміналістичних досліджень залишається тактичне забезпечення досудового розслідування та судового провадження злочинів. Окремим питанням цієї сфери наукових інтересів і практичних потреб є проблема використання даних про жертву злочину (потерпілого) під час підготовки та проведення слідчих (розшукових) дій. Так, вони є дієвими й надійними засобами збирання, дослідження, оцінювання, використання та перевірення доказів у кримінальному провадженні, формування належної, достатньої й допустимої доказової бази. Підготовка та проведення слідчих (розшукових) дій відбувається на базі встановлених у кримінальному провадженні фактичних даних про різні обставини й учасників злочину, серед яких певне місце займають і віктимологічні дані.

У криміналістиці проблема використання віктимологічних даних у процесі підготовки й проведення слідчих (розшукових) дій частково досліджувалась у працях В. М. Бикова та В. С. Бурданової, В. В. Вандишева, В. А. Журавля, В. Ю. Шепітька, С. О. Центрова, В. І. Шиканова й ін. ${ }^{2}$ Аналізу під-

1 Див.: Сдиний звіт про кримінальні правопорушення за січень - грудень 2013 р.; Сдиний звіт про кримінальні правопорушення за січень - грудень 2014 р.; Сдиний звіт про кримінальні правопорушення за січень - червень 2015 р. [Електронний pecypc]. — Режим доступу: http://www.gp.gov.ua.

Див.: Бурданова В. С. Виктимологические аспекты криминалистики : учеб. пособие / В. С. Бурданова, В. М. Быков. - Ташкент : Изд-во Ташк. ВШ МВД СССР, 1981. - 79 с.; Вандышев В. В. Теоретические и практические аспекты взаимосвязи криминалистики и виктимологии : автореф. дис. на соискание уч. степени канд. юрид. наук : спец. 12.00.09 «Уголовный процесс; криминалистика» / В. В. Вандышев. - М., 1989. - 34 с.; Журавель В. А. Допрос потерпевшего и использование его показаний для построения методики расследования отдельных видов преступлений : автореф. дис. на соискание уч. степени канд. юрид. наук : спец. 12.00 .09 «Уголовный процесс; судоустройство; прокурорский надзор; криминалистика» / В. А. Журавель. - Х., 1983. - 17 с.; Потерпілий від злочину (міждисциплінарне правове дослідження) / за заг. ред. Ю. В. Бауліна, В. І. Борисова. — Х. : Кроссроуд, 2008. - 364 с.; Центров Е. Е. 
давалась тактика окремих слідчих (розшукових) дій за участю потерпілого (огляд місця події, обшук, пред'явлення для впізнання). Особливу увагу приділяли дослідженню тактики допиту потерпілих Г. Г. Доспулов, В. А. Журавель, М. Н. Нагімов, О. Б. Соловйов, В. Ю. Шепітько та ін. ${ }^{1}$ Однак проблема використання віктимологічних даних під час підготовки й проведення слідчих (розшукових) дій залишається недостатньо вивченою. Зазначені наукові роботи здебільшого лише частково висвітлюють особливості використання віктимологічних даних у підготовці й проведені певних слідчих (розшукових) дій. Комплексні ж дослідження цієї проблеми в літературі зустрічаються рідко. До того ж увага приділяється слідчим (розшуковим) діям, участь у проведенні яких бере потерпілий. Однак віктимологічні дані можуть успішно використовуватися в підготовці та проведенні слідчих (розшукових) дій, у яких потерпілий участі не приймає. Недоліком треба вважати й відсутність класифікації слідчих (розшукових) дій за критерієм специфіки використання віктимологічних даних під час їх підготовки та проведення. Такий підхід дозволив би встановити закономірності використання віктимологічних даних у ході підготовки й проведення певного виду слідчих (розшукових) дій.

Актуальність наукового дослідження закономірностей використання віктимологічних даних у процесі підготовки та проведення слідчих (розшукових) дій підсилює й чинний КПК України, який реформував національне кримінальне судочинство та правоохоронну систему, привів їх у відповідність до європейських стандартів. Зміни, унесені КПК України в модель вітчизняного кримінального судочинства, слідчу й судову практику вимагають переосмислення наукової проблеми криміналістичного забезпечення слідчих (розшукових) дій у кримінальному провадженні. Норми КПК України, новації у сфері досудового розслідування та провадження слідчих (розшукових) дій вимагають ревізування теоретичних положень і практичних рекомендації криміналістичної тактики, розроблення нових і приведення

Криминалистическое учение о потерпевшем / Е. Е. Центров. - М. : Изд-во Моск. гос. ун-та, 1988. - 160 с.; Шиканов В. И. Криминалистическая виктимология и практика расследования убийств : учеб. пособие / В. И. Шиканов. - Иркутск : Издво Иркутск. ун-та, 1979. - 44 с.

Див.: Доспулов Г. Г. Процессуальные и психологические основы допроса свидетелей и потерпевших на предварительном следствии : автореф. дис. на соискание уч. степени канд. юрид. наук : спец. 715 «Уголовное право и уголовный процесс» / Г. Г. Доспулов. - Алма-Ата, 1968. - 19 с.; Журавель В. А. Допрос потерпевшего и использование его показаний для построения методики расследования отдельных видов преступлений; Нагимов М. Н. Процессуально-психологические особенности допроса потерпевшего в советском уголов-ном процессе : автореф. дис. на соискание уч. степени канд. юрид. наук : спец. 12.00.09 «Уголовный процесс; судоустройство; прокурорский надзор; криминалистика» / М. Н. Нагимов. — Ташкент, 1986. — 26 с.; Сoловьев А. Б. Допрос свидетеля и потерпевшего / А. Б. Соловьев. - М. : Всесоюз. ин-т по изуч. причин и разраб. мер предупреждения преступности, 1974. - 128 с.; Wenimbко В. Ю. Допит потерпілого: тактико-психологічний підхід / В. Ю. Шепітько // Питання боротьби зі злочинністю. - Х. : Кроссроуд, 2008. - Вип. 15. - С. 256-265. 
наявних рекомендацій у відповідність до положень кримінального процесуального законодавства та правозастосовної практики. Першочерговим завданням у вирішенні проблеми використання віктимологічних даних у тактиці слідчих (розшукових) дій є аналізування кримінального процесуального регулювання інституту слідчих (розшукових) дій.

Інститут слідчих (розшукових) дій регулюється КПК України та підзаконними нормативно-правовими актами. Підстави й порядок проведення слідчих (розшукових) дій і негласних слідчих (розшукових) дій передбачені в главах 20 та 21 КПК України. За чинним кримінальним процесуальним законодавством інститут слідчих (розшукових) дій зазнав істотних змін: оновлений вигляд має назва цієї групи процесуальних дій; уперше закріплено визначення поняття слідчих (розшукових) дій ${ }^{1}$; останні розподілено на групи: «традиційні» та негласні; уведено новий інститут негласних слідчих (розшукових) дій, визначено підстави й порядок їх проведення; змінено назви деяких слідчих (розшукових) дій, підстави та порядок їх проведення; окремі слідчі (розшукові) дії або ліквідовані, або трансформовано в інші процесуальні дії; установлено загальні вимоги до проведення таких дій.

Кримінально-процесуальний інститут слідчих (розшукових) дій сьогодні залишається одним із найбільш спірних. Наукові дискусії виникають, зокрема, стосовно визначення поняття та класифікації слідчих (розшукових) дій. Так, у ч. 1 ст. 223 КПК України закріплено, що слідчі (розшукові) дії-це дії, спрямовані на отримання (збирання) доказів або перевірку вже отриманих доказів у конкретному кримінальному провадженні. Хоча вчені й зауважують, що таке визначення є традиційним для науки кримінального процесу ${ }^{2}$, проте цитована дефініція не сприяла вирішенню існуючих наукових дискусій з цього приводу, a, навпаки, посилила їх, оскільки КПК України не врахував істотні ознаки слідчих дій. Визначення мети проведення слідчих (розшукових) дій указівкою на «отримання (збирання)» $\mathrm{i}$ «перевірку» доказів не відображає всього обсягу роботи $з$ доказами, що проводиться під час цих дій у процесі розслідування злочинів. Таке визначення фактично унеможливило включення до його складу функції оцінювання доказів. Більш обгрунтовані визначення поняття слідчих (розшукових) дій пропонують учені ${ }^{3}$.

1 Див.: Сергєєва Д. Б. Поняття та види слідчих (розшукових) дій за чинним КПК України / Д. Б. Сергєєва // Право України. — 2013. - № 11. - С. 180.

2 Див.: Капліна О. В. Проблеми тлумачення загальних вимог до проведення слідчих (розшукових) дій / О. В. Капліна // Актуальні проблеми кримінального права, процесу та криміналістики : матеріали IV міжнар. наук.-практ. конф., присвяч. 95-річчю $з$ дня народж. проф. М. В. Салтевського (1917-2009), Одеса, 2 лист. 2012 р. - Одеса : Фенікс, 2012. - С. 339.

Див., напр.: Погорецький М. А. Функціональне призначення оперативно-розшукової діяльності у кримінальному процесі : монографія / М. А. Погорецький. - Х. : Арсіс, 2007. - С. 393; Сергєєва Д. Б. Указ. праця. - С. 182-183; Тертишник В. М. Кримінальний процес України. Особлива частина : підручник / В. М. Тертишник. К. : Правова єдність, 2014. - С. 18; Кримінальне процесуальне право України : навч. посібник / К. В. Беляєва [та ін.] ; за заг. ред. В. Г. Гончаренка, В. А. Колесника. - К. : Юстініан, 2014. - С. 299. 
Сьогодні серед учених тривають дискусії й з приводу системи слідчих (розшукових) дій. Вирішення цього питання натепер ускладнюється новими підходами до розуміння поняття й видів слідчих (розшукових) дій у КПК України ${ }^{1}$, який закріплює окремі слідчі (розшукові) дії, що згруповано умовно чи в деяких випадках навіть безпідставно. Лише системне тлумачення норм глав 20 і 21 КПК України дозволяє зробити висновок, що слідчі (розшукові) дії поділяються на дві групи: слідчі (розшукові) дії та негласні слідчі (розшукові) дії. Система слідчих (розшукових) дій подається такими традиційними діями, як: допит (статті 224-226, 232 КПК України): свідка, потерпілого (у тому числі й під час досудового розслідування в судовому засіданні), підозрюваного, малолітньої або неповнолітньої особи, допит у режимі відеоконференції, одночасний допит двох чи більше вже допитаних осіб; пред'явлення для впізнання: особи (ст. 228 КПК України), речей (ст. 229 КПК України), трупа (ст. 230 КПК України); обшук: житла чи іншого володіння особи, особи, яка перебуває в житлі чи іншому володінні (статті 233-236 КПК України); огляд: місцевості, приміщень, житла чи іншого володіння особи, речей і документів (ст. 237 КПК України), трупа, у тому числі й пов'язаного з ексгумацією (статті 238-239 КПК України), місця вчинення кримінального правопорушення (п. 2 ч. 2 ст. 520 КПК України); освідування особи (ст. 241 КПК України); слідчий експеримент (ст. 240 КПК України); залучення експерта (статті 242-243 КПК України $)^{2}$. Поруч із цим у КПК України запропонована система негласних слідчих (розщукових) дій․․ Проте проблема їх змістовного наповнення, тактико-криміналістичних засобів їх реалізації залишається невирішеною ${ }^{4}$. Негласні слідчі (розшукові) дії, на відміну від слідчих (розшукових) дій, проводяться таємно, відомості про факт і методи їх проведення не підлягають розголошенню (ч. 1 ст. 246 КПК України). Кодекс закріплює лише

1 Див.: Котюк O. I. Класифікація слідчих дій - нові підстави і старі проблеми / О. І. Котюк // Бюл. М-ва юстиції України. — 2012. — № 4. — С. 149-155.

2 КПК України втратив такі традиційні слідчі (розшукові) дії, як: виїмка, відтворення обстановки й обставин події та перевірка показань на місці. Очна ставка й призначення експертизи змінили свої назви.

3 Відповідно до гл. 21 КПК України система негласних слідчих (розшукових) дій складається 3 двох груп. Перша група включає діï, пов'язані із втручанням $у$ приватне спілкування: аудіо-, відеоконтроль особи; накладення арешту на кореспонденцію, іiі огляд і виїмка; зняття інформації з транспортних телекомунікаційних мереж; зняття інформації з електронних інформаційних систем. Друга група включає інші негласні слідчі (розшукові) дї̈: обстеження публічно недоступних місць, житла чи іншого володіння особи; установлення місцезнаходження радіоелектронного засобу; спостереження за особою, річчю або місцем; аудіо-, відеоконтроль місця; контроль за вчиненням злочину; виконання спеціального завдання з розкриття злочинної діяльності організованої групи чи злочинної організації; негласне отримання зразків, необхідних для порівняльного дослідження; використання конфіденційного співробітництва.

4 Див. : Шепитько В. Ю. Система следственных действий в структуре уголовно-процессуального закона и криминалистической тактики / В. Ю. Шепитько // Ежегод. укр. права : сб. науч. тр. - Х. : Право, 2014. — № 6. - С. 531-532. 
загальні умови проведення негласних слідчих (розшукових) дій, порядок отримання дозволів на їх проведення, особливості фіксації ходу та результатів. Для додаткового врегулювання цього питання були запроваджені підзаконні міжвідомчі нормативно-правові акти ${ }^{1}$.

У криміналістиці виокремлюються різні підстави класифікації слідчих (розшукових) дій. 3 огляду на проблему використання віктимологічних даних у підготовці та проведені слідчих (розшукових) дій, такі дії також можуть певним чином диференціюватися. Так, залежно від особливостей використання віктимологічних даних у тактиці слідчих (розшукових) дій, останні поділяються на: 1) дії, підготування й проведення яких неможливо без використання віктимологічних даних, їх залучення обов'язкове (наприклад, допит потерпілого); 2) дії, у підготовці та проведенні яких віктимологічні дані не використовуються (залучення експертів для проведення деяких видів судових експертиз); 3) дії, тактика яких може вимагати залучення віктимологічних даних як факультативної базиㄹ. Залежно ж від участі потерпілого в слідчих (розшукових) діях, виокремлюють: дії, що проводяться за участю потерпілого та дії, які проводяться без його участі. Перша група, у свою чергу, поділяється на слідчі (розшукові) дії, участь у яких потерпілого обов'язкова та такі, що не вимагають обов'язкової його участі. Залежно ж від мети залучення потерпілого до проведення слідчих (розшукових) дій вони поділяються на такі, що: забезпечують отримання інформації від потерпілого; сприяють перевіренню його показань; пов'язані з його участю в пошуковій діяльності; спрямовані на дослідження потерпілого ${ }^{3}$. Проте віктимологічні дані можуть використовуватися для визначення позиції слідчого й обрання тактики проведення слідчих дій, участі в яких потерпілий не приймає $\epsilon^{4}$. Ці дані дозволять установити нову інформацію, відшукати докази й перевірити виявлені факти, оцінити інформацію, що надходить від учасників кримінального провадження.

Узагальнення кримінальних проваджень, що розслідувалися за фактом учинення вбивства, нанесення тяжкого тілесного ушкодження, згвалтування та протоколів слідчих (розшукових) дій, надало змогу встановити, що

1 Див.: Про затвердження Інструкції про організацію проведення негласних слідчих (розшукових) дій та використання їх результатів у кримінальному провадженні : наказ Ген. прокуратури України, МВС України, СБ України, Адміністрації Держ. прикордонної служби України, М-ва фінансів України, М-ва юстиції України від 16.11.2012 № 114/1042/516/1199-/936/1687/5 [Електронний ресурс]. — Режим доступу : http://zakon2.rada. gov.ua/laws/show/v0114900-12.

Така градація слідчих (розшукових) дій має умовний характер і навести вичерпний перелік кожної групи неможливо через те, що тактика слідчих (розшукових) дій має значну ситуаційну зумовленість і може бути пов'язана з участю потерпілого в провадженні цих дій.

3 Див.: Бурданова В. С., Быков В. М. Указ. праця. - С. 25; Вандышев В. В. Изучение личности потерпевшего в процессе расследования : учеб. пособие / В. В. Вандышев. - Ленинград : ЛВК МВД СССР, 1989. — С. 54-55.

4 Див. : Вандымев В. В. Изучение личности потерпевшего в процессе расследования. - С. 54-55. 
лише 38 \% протоколів указували на використання віктимологічних даних у проведені слідчих (розшукових) дій. Останнє спричинено складністю й трудомісткістю процесу встановлення віктимологічних даних у кримінальному провадженні, недостатнім усвідомленням можливостей, які відкривають такі дані у сфері тактичного забезпечення процесу розслідування злочинів. Результати анкетування слідчих і співробітників оперативних підрозділів органів МВС України, СБ України, прокурорів прокуратури України, яким установлено, що на думку $28 \%$ респондентів вивчення особи жертви злочину (потерпілого) допомагає ефективно планувати й обирати тактику проведення системи слідчих (розшукових) дій, негласних слідчих (розшукових) дій, оперативно-розшукових заходів і судових дій. Основною причиною недостатнього використання віктимологічних даних у процесі підготовки й проведення слідчих (розшукових) дій є поверхневе вивчення особи жертви злочину (потерпілого) та вибіркове встановлення віктимологічних даних ${ }^{1}$. Під час досудового розслідування злочинів превалює «шаблонний» підхід у процесі дослідження жертв злочинів (потерпілих) ${ }^{2}$. Складність установлення віктимологічних даних у кримінальному провадженні, спричинена цим проблема використання таких даних у процесі підготовки й проведення слідчих (розшукових) дій, переконує в необхідності розроблення та впровадження програми дослідження жертви злочину (потерпілого) ${ }^{3}$. Сьогодні вченими розроблюються універсальні та спеціальні програми дослідження жертви злочину (потерпілого) ${ }^{4}$. Такі програми $є$ результатом розвитку криміналістичної віктимології. У той самий час можемо констатувати

1 Анкетуванням слідчих і співробітників оперативних підрозділів органів МВС України, СБ України, прокурорів прокуратури України встановлено, що на думку респондентів для успішного розкриття й розслідування злочину необхідно встановлювати такі віктимологічні дані: загальні демографічні дані - 14\%; соціально-психологічні дані - 42\%; дані про діяльність і матеріальне становище - 56\%; дані про соціальні зв'язки - 54\%; дані про особливості поведінки та відомості про віктимність $-48 \%$; злочинний досвід - 18\%. На необхідність встановлювати всі перераховані віктимологічні дані вказали $6 \%$ опитаних респондентів.

2 Установлення «мінімуму» віктимологічних даних може бути пов'язане 3 : формалізацією кримінального провадження; професійною деформацією працівників правоохоронних органів або недостатньою підготовкою; перевантаженням слідчих, на яких одночасно припадає від 60 до 150 кримінальних проваджень (див.: Гончарук $H$. Кожен вінницький слідчий розслідує в середньому близько 100-150 кримінальних проваджень / Н. Гончарук [Електронний ресурс]. - Режим доступу : http://mvs.gov.ua/mvs/control/vinnytsia/).

Анкетуванням слідчих і співробітників оперативних підрозділів органів МВС України, СБ України, прокурорів прокуратури України встановлено, що на думку $70 \%$ респондентів дані про жертву злочину доцільно збирати саме за типовою програмою.

4 Див.: Вандымев В. В. Теоретические и практические аспекты взаимосвязи криминалистики и виктимологии. - С. 19-20; Гурев М. С. Убийства на «разборках» (методика расследования) / М. С. Гурев. - СПб. : Питер, 2001. - С. 76-77; Wenimbко В. Ю. Вибрані твори / В. Ю. Шепітько. - Х. : Вид. агенція «Апостіль», 2010. C. $433-434$. 
їх недосконалість (наприклад, відсутність рекомендацій з приводу джерел, способів і методів установлення віктимологічних даних), усунути яку можливо через імплементацію зарубіжних програм вивчення жертв злочинів і розроблення на їх основі нових, удосконалених програм, які б відповідали вимогам національної правозастосовної практики.

Зарубіжні фахівці в галузі судової віктимології та профілювання (США) пропонують складати профіль (profile) жертви злочину. Наприклад, В. Turvey розробив перелік даних, необхідних для встановлення віктимологічної інформації, що може бути корисною в розслідуванні злочинів ${ }^{1}$. Профайлер рекомендує встановлювати такі «блоки» даних про жертву злочину: особисті дані; електронно-цифрові дані; дані про місце проживання; про зв'язки та відносини; дані про зайнятість і діяльність; фінансові дані; медичні дані; судові дані. Створення портрета жертви злочину вимагає реконструкції останніх 24 год життя такої особи з метою ознайомлення віктимолога 3 діяльністю жертви, установлення інформації про те, яким чином вона опинилась у певному місці й у певний час, що дозволило злочинцю їі «дістатися» ${ }^{2}$. Подібне дослідження в криміналістичній літературі ще називають тактичним прийомом «реставраиія способу життя та поведінки потерпілого»", 3 чим важко погодитися ${ }^{4}$. Програма вивчення жертви злочину (потерпілого) формалізує окремий напрям слідчої діяльності ${ }^{5}$,iї метою $є$ оптимізація такої діяльності та підвищення іiї ефективності ${ }^{6}$. Це типова програма, котра по-

1 Учені наголошують, що жодного «контрольного списку» не буде достатньо, тому віктимолог (слідчий, профайлер) має бути готовим до ретельного дослідження «історії жертви злочину» без упереджених суджень. Установленні дані про жертву злочину порівнюються з іншою інформацією й оцінюються слідчим, що забезпечує якісне досудове розслідування та судове провадження (див.: Turvey B. E. Criminal Profiling : An Introduction to Behavioral Evidence Analysis / B. E. Turvey. - Fourth Ed. — Forensic Solutions, LLC Sitka. — Alaska, USA, 2012. — P. 182).

2 Див.: Turvey B. E. Указ. праця. - Р. 182.

3 Див.: Курс криминалистики. Особенная часть / отв. ред.-сост. В. Е. Корноухов. - М. : Юристь. - Т. 1. Методики расследования насильственных и корыстнонасильственных преступлений. - 2001. - С. 108-110.

4 На нашу думку, мова має йти не про окремий тактичний прийом, а про окрему тактичну операцію або їх систему. Необхідно погодитися зі С. Ф. Здоровко, який указує, що встановлення особи жертви злочину є проміжним (тактичним) завданням розслідування, зокрема вбивств, учинених організованими злочинними групами, допомогти вирішити яке покликана система типових тактичних операцій. Учений запропонував у межах вирішення зазначеного тактичного завдання виокремлювати такі тактичні операції: «Ідентифікація невпізнанного трупа» («Атрибуція трупа»); «Соціальний статус жертви»; «Зв’язки жертви». Цікавою є тактична операція «Віктимність жертви», яка спрямована на встановлення мотивів убивства (див.: Здоровко С. Ф. Типові тактичні операції при розслідуванні вбивств, вчинених організованими злочинними групами / С. Ф. Здоровко. - Х. : Нац. юрид. акад. України ім. Я. Мудрого, 2002. - С. 20-30).

Див.: Щур Б. В. Теоретичні основи формування та застосування криміналістичних методик : монографія / Б. В. Щур. - Х. : Харків юридичний, 2010. - С. 252.

6 Див.: Журавель В. А. Проблеми формалізації слідчої діяльності / В. А. Журавель // Реформування судових і правоохоронних органів України: проблеми та перспективи : матеріали наук.-практ. конф., Харків, 14 трав. 2010 р. - Х., 2010. - С. 354-355. 
кликана допомогти зібрати віктимологічні дані в кримінальному провадженні. Відправною точкою їі розроблення має стати концепція «віктимологічних даних», а сама вона має містити не тільки перелік віктимологічних даних, які слідчий повинен установити, а й указувати на джерела, способи та методи отримання таких даних ${ }^{1}$. Аналізована програма має орієнтувати органи досудового розслідування на встановлення системи віктимологічних даних у результаті вивчення об'єктивних і суб'єктивних джерел, різними процесуальними та непроцесуальними способами. На нашу думку, програма дослідження жертви злочину (потерпілого) має складатися з окремих блоків віктимологічних даних: 1) відомостей про ознаки зовнішності та зовнішній вигляд жертви злочину (потерпілого); 2) загальних демографічних даних; 3) соціально-психологічних даних; 4) медичних даних; 5) інформації про соціальні зв'язки й відносини; 6) відомостей про зайнятість і діяльність; 7) даних про фінансовий стан; 8) даних про місце проживання; 9) інформації про життя жертви злочину, що збереглася в електронному чи віртуальному просторі; 10) відомостей про правопорушення та судові процеси за участю потерпілого; 11) даних про поведінку; 12) інформації про віктимність; 13) відомостей про шляхи, маршрути й засоби пересування жертви злочину. Такі блоки даних значно диференціюються. Джерелами даних про жертву злочину (потерпілого) є документи, усні заяви та повідомлення, що містять віктимологічні дані (протоколи проведення слідчих (розшукових) дій, характеристики з місця роботи чи навчання, медичні картки та історії хвороби, результати опитування близького оточення тощо) або результати безпосереднього спостереження слідчого, прокурора, судді або співробітника оперативного підрозділу. Способами встановлення віктимологічних даних $\epsilon$ проведення слідчих (розшукових) дій, негласних слідчих (розшукових) дій i оперативно-розшукових заходів. Методами вивчення особи жертви злочину є метод спостереження, бесіди, тестування, інтерв'ювання, метод незалежних характеристик та ін.

Віктимологічні дані можуть успішно використовуватись у підготовці та проведенні слідчих (розшукових) і негласних слідчих (розшукових) дій. Серед слідчих (розшукових) дій віктимологічні дані ефективно можуть використовуватись у підготовці та проведені таких дій: огляд (трупа, місцевості, житла чи іншого володіння особи, речей, документів), допит (свідка, підозрюваного, потерпілого), одночасний допит двох чи більше вже допитаних осіб (потерпілих, свідків, підозрюваних) пред'явленні для впізнання (особи, речей або трупа), обшук (житла чи іншого володіння особи, особи,

1 Анкетуванням слідчих і співробітників оперативних підрозділів органів МВС України, СБ України, прокурорів прокуратури України встановлено, що найчастіше джерелами даних про особу та поведінку жертви злочину (потерпілого) є: показання очевидців і свідків - 54\%; допити родичів і знайомих - $64 \%$; відомості та характеристики з місця роботи, навчання, проживання - 35\%; результати проведення слідчих (розшукових) дій - 33\%; результати проведення негласних слідчих (розшукових) дій $-31 \%$; результати проведення оперативно-розшукових заходів - $15 \%$; особисте спілкування з потерпілим - 1\%. 
яка перебуває у житлі чи іншому володінні особи), слідчий експеримент, освідування, отримання зразків для експертизи, залучення експерта. У такому разі можуть бути корисними різні за характером групи віктимологічних даних або окремі дані: біологічні відомості про жертву злочину (іi загальнофізичні особливості, анатомічні, функціональні, генетичні дані, стан здоров'я та ін.); соціальні (загальні демографічні дані, дані про соціальні зв'язки й відносини жертви злочину, їі матеріальне становище тощо), психологічні дані (риси характеру, потреби, мотиви, культурний та інтелектуальний рівні, психічні, емоційні стани та ін.), дані про особливості поведінки (до, під час і після злочинного посягання). Якщо відомості про злочин та особу, яка його вчинила, неможливо отримати в інший спосіб і йдеться про розслідування тяжкого й особливо тяжкого злочину, віктимологічні дані можуть використовуватися в підготовці та проведенні деяких негласних слідчи (розиукових) діü, виступаючи їх додатковою інформаційною основою (спеціальний слідчий експеримент, імітування обстановки вчинення злочину).

Використання віктимологічних даних у процесі підготовки й проведення слідчих (розшукових) дій підкорено закономірностям, існування яких викликано категорією злочину, слідчою ситуацією, природою та видом процесуальної дії, об’єктом тактичного впливу, її метою й завданнями. Розслідування тяжких тілесних ушкоджень передбачає проведення системи слідчих (розшукових) дій, що потребує використання віктимологічних даних ${ }^{1}$. Науковий аналіз протоколів слідчих (розшукових) дій у зазначеній категорії

1 Узагальнення кримінальних проваджень, порушених у зв'язку з нанесенням тяжких тілесних ушкоджень дало змогу встановити, що під час розслідування цієї категорії злочинів проводять такі слідчі (розшукові) дії: огляд місця події - 84,28\%; огляд трупа $-40 \%$; огляд місцевості, житла або іншого володіння особи $-97,14 \%$; огляд речей $-87,14 \%$; допит підозрюваного - $100 \%$; допит потерпілого - $80 \%$; допит свідків - 98,57\%; одночасний допит двох чи більше допитаних осіб - 75,71\%; пред'явлення для впізнання особи - 32,85\%; пред'явлення для впізнання речей $14,28 \%$; обшук житла чи іншого володіння особи - $58,57 \%$; слідчий експеримент $95,71 \%$; освідування - $15,85 \%$; одержання зразків - $8,57 \%$; залучення експерта - $100 \%$ узагальнених справ. Дослідження протоколів огляду місця події дозволило встановити, що в 59,32\% випадків використовувалися дані про поведінку жертви злочину (потерпілого), а в 40,67\% - біологічні дані (якщо вони встановлені до моменту проведення дій). Якщо нанесення тяжкого тілесного ушкодження спричинило настання смерті потерпілого (ч. 2 ст. 121 КК України), то проводився огляд трупа жертви злочину, у якому біологічні дані застосовувалися в 39,28\% випадків, соціальні дані $32,14 \%$, дані про поведінку потерпілого - 59,32\% випадків. Під час допиту підозрюваного, наприклад, біологічні дані про потерпілого використовувалися в $12,85 \%$, соціальні дані в 32,85\%, а дані про поведінку потерпілого в 97,14\% випадків. У ході допиту свідків психологічні дані про жертву злочину застосовувалися у $18,84 \%$ випадків, соціальні дані - 62,31\%, біологічні дані - 34,78\% і дані про поведінку - 97,1\% випадків. У процесі одночасних допитів двох чи більше осіб використовуються такі віктимологічні дані: соціальні дані - 43,39\% випадків; психологічні дані - 24,52\%; дані про поведінку жертви злочину - 98,11\% випадків. Проведення слідчого експерименту передбачало використання біологічних даних потерпілого в 17,91\% та даних про поведінку жертви злочину у 82,08\% випадків. 
злочинів дає підстави для висновків: 1) біологічні дані про жертву злочину (потерпілого) найчастіше використовуються в процесі залучення експертів i, як результат, під час проведення самих експертиз (судово-медичної та судово-психіатричної експертиз), одержання зразків, огляду місця події, трупа й речей; 2) соціальні дані здебільшого застосовуються в ході допиту свідків, підозрюваного та потерпілого, одночасного допиту двох або більше вже допитаних осіб, пред’явлення для впізнання особи чи речей (як правило, потерпілого); 3) психологічні дані в процесі проведення слідчих (розшукових) дій використовуються рідко i, як правило, під час пред'явлення для впізнання особи, одночасному допиті двох чи більше вже допитаних осіб, допиті потерпілого або свідка; 4) дані про поведінку жертви злочину (потерпілого) застосовуються в ході проведення слідчих (розшукових) дій найчастіше (допит потерпілого, підозрюваного, свідків, одночасний допит двох чи більше вже допитаних осіб, слідчий експеримент, освідування особи, залучення експерта, одержання зразків, огляд місця події та ін.).

Таким чином, використання віктимологічних даних у процесі підготовки й проведення слідчих (розшукових) дій забезпечує реалізацію завдань кримінального судочинства щодо повного, швидкого та неупередженого дослідження всіх обставин кримінального провадження й розслідування кримінального правопорушення.

\section{ПРОБЛЕМЫ ИСПОЛЬЗОВАНИЯ ВИКТИМОЛОГИЧЕСКИХ ДАННЫХ В ПРОЦЕССЕ ПОДГОТОВКИ И ПРОВЕДЕНИЯ СЛЕДСТВЕННЫХ (РОЗЫСКНЫХ) ДЕЙСТВИЙ}

\section{Резникова Е. И.}

Рассмотрен криминалистический аспект проблемы использования виктимологических данных во время подготовки и проведения следственных (розыскных) действий, установлены основные проблемы использования таких данных и пути их решения. Предложены отдельные научно-практические рекомендации, призванные повысить эффективность процесса собирания и использования виктимологических данных в уголовном производстве.

Ключевые слова: жертва преступления, потерпевший, виктимологические данные, программа исследования жертвы (потерпевщего), профиль жертвы (потерпевшего).

\section{ON THE PROBLEM OF USING VICTIMOLOGICAL DATA IN THE PROCESS OF PREPARING AND CONDUCTING INVESTIGATION (SEARCH) ACTIONS}

\section{Reznikova O. I.}

Based on the generalized analysis of modern law enforcement practice in Ukraine, the article concludes that during the pre-trial investigation into certain types of crimes the person of the victim (the injured party) is not given a proper and thorough examination. The article suggests certain scientific and practical 
recommendations in order to increase the efficiency of the process of collecting and using victimological data in criminal legal proceedings. It studies the capacity of drafting the victim's (the injured party's) profile and offers a new program to study the victim of a crime (the injured party), this program serves as a basis for collecting and using victimological data in criminal legal proceedings, as well as a basis for building a profile of not only a victim (of a crime), but of a criminal as well. The article substantiates that the use of victimological data in preparing for and conducting investigation (search) actions follows certain patterns that include the peculiarities of the category of crimes under investigation, the investigation situation, the nature and type of proceedings, the object of tactical impact, the aim and tasks of an investigation (search) action.

Keywords: victim of the crime, injured party, victimological data, program to study the victim (the injured party), victim's (the injured party's) profile, investigation (search) actions. криміналістики Національного юридичного університету імені Ярослава Мудрого

\section{ДОКУМЕНТООБІГ І ЙОГО ЗНАЧЕННЯ ПРИ РОЗСЛІДУВАННІ ПОРУШЕНЬ ПРАВИЛ БЕЗПЕКИ ПІД ЧАС ВИКОНАННЯ РОБІТ ІЗ ПІДВИЩЕНОЮ НЕБЕЗПЕКОЮ}

Досліджено особливості документообігу та його значення при розслідуванні порушень правил безпеки під час виконання робіт із підвищеною небезпекою на основі даних узагальнення кримінальних справ (матеріалів кримінального провадження).

Ключові слова: документообіг, відомче розслідування, порушення правил безпеки при виконанні робіт із підвищеною небезпекою.

Особливості господарської та організаційної діяльності будь-якого підприємства, установи, організації незалежно від форми власності відображується у відповідній відомчій документації, що відбиває хід і результати господарювання. Водночас виконання робіт із підвищеною небезпекою супроводжується особливим порядком документообігу на підприємстві, що складається з відповідних договорів, наказів, розпоряджень, супровідної документації, при вивченні якої в слідчого формується повна картина порушення правил безпеки, що мала місце в минулому. Крім документації підприємства, на якому сталося порушення, особливого значення набуває й документація відомчого розслідування порушення.

У наукових працях, присвячених розслідуванню порушень правил безпеки під час виконання робіт із підвищеною небезпекою, головна увага 